\title{
Seed Management and Quality of Farmer Saved Seeds of Bambara groundnut from North Western, Northern and Eastern Uganda
}

M. OBURA*, G. OBALliM, J. O. OCHUODHO, F. N.W MAINA \& V. E. ANJICHI

(M.O, G.O, J.O.O, F.N.W.M \& V.E.A.: Department of Seed, Crop and Horticultural Sciences, University of Eldoret P.O. Box 1125-30100 Eldoret, Kenya; G.O.: National Agricultural Research Organisation; Abi Zonal Agricultural Research and Development Institute P.O. Box 219 Arua, Uganda)

*Corresponding author's email: oburamorish100@gmail.com

\begin{abstract}
Bambara groundnut (BG) is a protein and energy-rich legume crop of African origin with the potential to contribute to food and nutrition security. There is limited information on seed management and quality of farmer saved seed of BG in Uganda. This study was conducted to investigate seed management practices and evaluate the quality of farmer saved seed from Uganda. Four hundred BG farmers were chosen using purposive sampling and information gathered on their seed management. A semi-structured questionnaire was used to interview the farmers. Seed colour and size determination, standard germination and electrical conductivity tests were done on seed samples collected from farmers. Results from survey revealed that farmers recycled seeds for more than 4 years $(39.2 \%)$ and maintained mostly single landraces $(52.5 \%)$. Seed was sun-dried on the ground $(81 \%)$, stored in gunny bags $(93.5 \%)$, and threshed mostly by hand $(52.0 \%)$. Collected landraces had varied seed coat colours and significantly differed at $p=0.05$ in their seed sizes, final germination percentage (FGP), electrical conductivity (EC), germination velocity index and seedling vigour index II (SVI-II). Local Bam landrace recorded highest SVI-II (485.3) and EC $\left(0.52 \mathrm{MSg}^{-1}\right)$ while TVSU 688 landrace recorded the highest FGP $(96.0 \%)$ and lowest EC $\left(0.06 \mathrm{MSg}^{-1}\right)$.
\end{abstract}

Keywords: Bambara groundnut; Farmer saved seeds; Farmers' seed management; Germination capacity; Seed vigour

Original scientific paper. Received 29 Jul 2020; revised 25 Apr 2021

\section{Introduction}

Bambara groundnut (Vigna subterranea L. Verdc) is an annual legume belonging to the family Fabaceae (APG IV, 2016). It is considered a food security crop because of its drought tolerance and ability to perform better than other crops in poor soils (Effa \& Uko,
2017; Tsoata et al., 2016; Anchirinah et al., 2001), yet it is one of the underutilized African legumes (Harouna et al., 2018). Bambara groundnut is a good nitrogen fixer thus complementary in cereal intercrops (Halimi et al., 2019; Sprent et al., 2010), and is also a good source of nutrients as the seeds contain

Ghana Jnl Agric. Sci. 56 (1), 1 - 15

GJAS is an Open Access Journal and distributed under the terms of the Creative Commons (CC) License [CC BY 4.0] 
$63 \%$ carbohydrate, $18 \%$ proteins and $6.5 \%$ fats (Bamishaiye et al., 2011). It can be consumed as fresh boiled or dried seeds ground into flour, spiced and made into paste or cakes (Jonah et al., 2010; Adebowale \& Lawal, 2002). Burkina Faso, Niger and Cameroon are the world's leading producers with annual production of about 42,514t, 21,416t and 20,705t respectively (FAO, 2019). Being a neglected crop, there are no commercial varieties available for cultivation (Mayes et al., 2008) and farmers use landraces whose seeds are exchanged and recycled for generations (Ibrahim et al., 2018). The quality of such recycled seeds is either low, variable or/ and unknown. Good quality seed is desirable in farming as it ensures uniform field stand, establishment and maturity, and has better response to added inputs. Good quality seed is that seed with all physical, physiological, pathological and genetic characteristics that contribute to yield (Basra, 1995). These quality characteristics are influenced by several factors including postharvest handling practices (Patel et al., 2018). Some studies have evaluated the physiological seed quality of Bambara groundnut landraces differing in seed coat colour (Mandizvo \& Odindo, 2019; Chibarabada et al., 2014), and its physical seed dormancy behaviour (Miya \& Modi, 2017), but there is still very limited information on the quality of farmers' saved seeds. In Uganda, there is very scarce information on farmers' seed handling practices and the quality of farmers' saved seeds of Bambara groundnut. This study was therefore undertaken to investigate seed management practices and evaluate the quality of farmers' saved seeds of Bambara groundnut from the predominant production areas of North Western, Northern and Eastern Uganda.

\section{Survey}

\section{Materials and Method}

A survey was conducted between June and July, 2019. Purposive sampling technique targeting Bambara groundnut farmers was used to select 400 respondents from North Western, Northern and Eastern Uganda. A total of 13 districts and 26 sub-counties were sampled in the predominant Bambara groundnut production areas of the country. One district (Nebbi) from North Western region, eight (Gulu, Omoro, Agago, Pader, Kole, Oyam, Otuke and Lira) from Northern region and four (Tororo, Kumi, Amuria and Kapelebyong) from Eastern region were chosen for the study. The selection of the number of districts per region was based on the information obtained from a reconnaissance study which revealed that Bambara groundnut production was more in Northern region, followed by Eastern and very limited production in North Western. A semistructured questionnaire was administered to the respondents to collect information on seed source, seed composition, period of seed recycling, time of seed selection, seed drying method, seed storage and seed processing prior to planting. Seed samples were also collected from farmers in each district during the survey and kept separately in paper bags. Data were analyzed using $\mathrm{IBM}^{\circ} \mathrm{SPSS}^{\circ}$ Statistics Version 20 statistical software (IBM Corporation, Armonk, New York, USA, 2011).

\section{Quality of farmers' saved seeds}

Collected seed samples were threshed carefully and gently with a stone, sorted according to the respective landraces and grouped by regions. From the samples, landraces AbiBam 001 and Local Bam (from Nebbi), AbiBam 003 (from Amuria), TVSU 688 (from Kapelebyong) and 
TVSU 759 (from Lira) were used for seed quality analysis. These landraces were selected for regional representation and availability of their seeds for laboratory analysis. Seed colour description was done using Royal Horticultural Society colour chart and seed size (length and width) was measured using a Vernier calliper. Electrical conductivity (EC) test was performed on three replicates of 10 seeds each. Seeds were separately weighed and soaked in deionized water for 24 hours and the conductivity of the leachate $\left(\mathrm{MSg}^{-1}\right)$ was measured with an EC meter. A standard germination test was performed with 25 seeds in three replications. Seeds were sterilized with $1 \%$ sodium hypochlorite solution for two minutes and rinsed with distilled water. The sterilized seeds were then placed in germination trays in sterilized sand moistened with distilled water. Seeds were incubated in growth chamber (BJPX-B40011, Biobase Biodustry (Shandong) Co. Ltd) at alternating temperature of $20^{\circ} \mathrm{C} / 30^{\circ} \mathrm{C}$ in 16 hours darkness and eight hours light for 14 days (Mandizvo \& Odindo 2019; Chibarabada et al., 2014), and germination count recorded daily. Final germination percentage (FGP) was determined on the $14^{\text {th }}$ day using the formula according to Nichols and Heydecker (1968) as $F G P=\frac{s}{T} \times 100$;

Where; $\mathrm{S}$ is the number of germinated seeds and $\mathrm{T}$ is the total number of seeds sown. Germination velocity index (GVI) was calculated according to Maguire (1962) as $\mathrm{GVI}=\mathrm{G}_{1} / \mathrm{N}_{1}+\mathrm{G}_{2} / \mathrm{N}_{2}+\ldots \ldots+\mathrm{G}_{\mathrm{n}} / \mathrm{N}_{\mathrm{n}}$ Where $G_{1}, G_{2} \ldots \ldots$... are number of seeds germinated on $1^{\text {st }}, 2^{\text {nd }}$ and last count. $\mathrm{N}_{1}, \mathrm{~N}_{2} \ldots \mathrm{N}_{\mathrm{n}}$ are number of days at $1^{\text {st }}, 2^{\text {nd }}$ and last count from the sowing day. 10 normal seedlings (normal seedlings had well-developed root and shoot systems) were oven-dried at $65^{\circ} \mathrm{C}$ for 48 hours and seedling dry weight (SDW) measured using a digital balance (TP-B2000). Seedling Vigour Index II (SVI-II) was computed by multiplying the final germination percentage with seedling dry weight (Abdul-Baki \& Anderson, 1973). Germination data were arcsine transformed and analysis of variance performed in GenStat ${ }^{\mathbb{B}}$ $14^{\text {th }}$ Edition (VSN International Ltd, Hemel Hempstead, UK, 2011). Least significant difference (LSD) was used to separate means at $5 \%$ significance level. A correlation of seed size and physiological seed quality parameters was done using Microsoft Excel 2016.

\section{Results}

\section{Seed sources}

The major seed sources were the local market $(35.2 \%)$ and farmers' own saved seeds (30.8\%) for most farmers. A higher percentage of farmers in North Western (55.2\%) and Northern $(30.9 \%)$ regions used their own saved seeds while $44.0 \%$ of those in the Eastern region sourced their seeds from local markets (Figure 1).

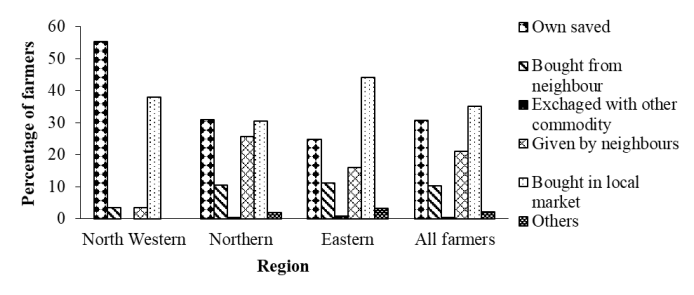

Fig. 1: Farmers' seed sources of Bambara groundnut 


\section{Seed composition}

Farmers used seed coat colours to differentiate landraces. A larger proportion of farmers had single $(52.5 \%)$ and mixed (33.5\%) landraces as opposed to "more than one not-mixed" landraces. More than half (65.5\%) of farmers in North Western region had mixed landraces while $60.2 \%$ and $44.0 \%$ of those in Northern and Eastern regions respectively had single landraces (Figure 2).

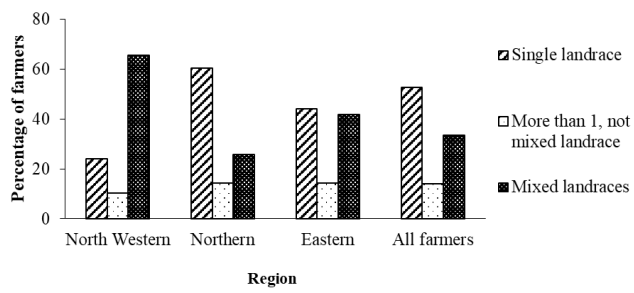

Fig. 2: Seed sample composition of Bambara groundnut

\section{Period of seed recycling}

Generally, farmers recycled the same seed for more than four years $(39.2 \%)$, two years $(22.8 \%)$ and three years $(21.0 \%)$. This was similar across all the three regions, with seed recycling for more than four years and two years dominating except for North Western region where seed recycling for three years was higher than that of two years (Table 1).

TABLE 1

Period of seed recycling among Bambara groundnut farmers

\begin{tabular}{lllll}
\hline \multicolumn{5}{c}{ Percentage of farmers } \\
\hline $\begin{array}{l}\text { Period } \\
\text { years) }\end{array}$ & $\begin{array}{l}\text { North } \\
\text { Western }\end{array}$ & Northern & Eastern & $\begin{array}{l}\text { All } \\
\text { farmers }\end{array}$ \\
\hline 1 & 6.9 & 9.3 & 7.2 & 8.5 \\
2 & 20.7 & 22.4 & 24.0 & 22.8 \\
3 & 24.1 & 19.5 & 23.2 & 21.0 \\
4 & 3.4 & 7.3 & 12.0 & 8.5 \\
$>4$ & 44.8 & 41.5 & 33.6 & 39.2 \\
\hline
\end{tabular}

\section{Seed selection}

Seed selection was common during drying $(47.8 \%)$ and at planting $(36.0 \%)$. Very few farmers selected seeds before the whole crop was harvested (1.8\%). Nonetheless, $20.7 \%$ of farmers in North Western region selected seeds during crop harvest (Figure 3). A larger percentage $(84.3 \%)$ of farmers did not use any seed selection criterion. However, a few farmers used big-sized pods, high-yielding plants and healthy-looking plants and pods as seed selection criteria (Figure 4).

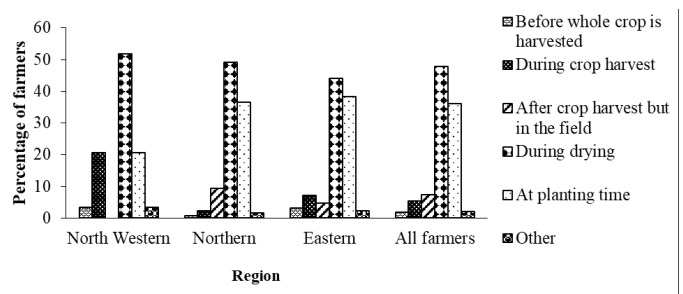

Fig. 3: Time of Bambara groundnut seed selection

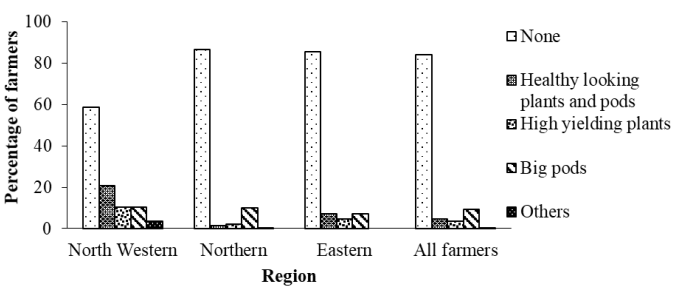

Fig. 4: Seed selection criteria among Bambara groundnut farmers

\section{Seed drying methods}

Generally, farmers dried Bambara groundnut directly on the ground $(81 \%)$ or on tarpaulin $(21.3 \%)$, a practice similar in all three regions (Figure 5). Farmers in Eastern region mostly used the sound of pods (pods are shaken during drying) (80\%) and hardness of seeds (70.4\%) to ascertain that Bambara groundnut was dry 
enough for storage. This was also similar to their counterparts in Northern region (Table 2).

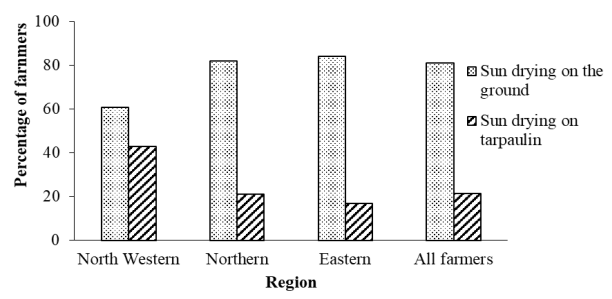

Fig. 5: Bambara groundnut seed drying methods

TABLE 2

Indicators of Bambara groundnut seed drying and suitability for storage

\begin{tabular}{lll}
\multicolumn{3}{c}{ Prying and suitability for storage } \\
\hline \multicolumn{3}{c}{ Percentage of farmers } \\
\hline $\begin{array}{l}\text { Indicator of seed } \\
\text { drying }\end{array}$ & Northern & Eastern \\
& & \\
\hline Sound of pods & 81.1 & 80.0 \\
Hardness of seeds & 57.0 & 70.4 \\
Duration of drying & 2.0 & 0.0 \\
Others & 4.9 & 1.6 \\
\hline
\end{tabular}

*This data was not captured for North Western region

\section{Seed storage methods}

Farmers in all the three regions stored Bambara groundnut in pods (in shells). The most preferred seed storage method was gunny bags on a raised platform (on stone, top of other produce or timber) $(93.5 \%)$ and this was common for all three regions. Only a few farmers stored Bambara groundnut in pots and open containers (Figure 6).

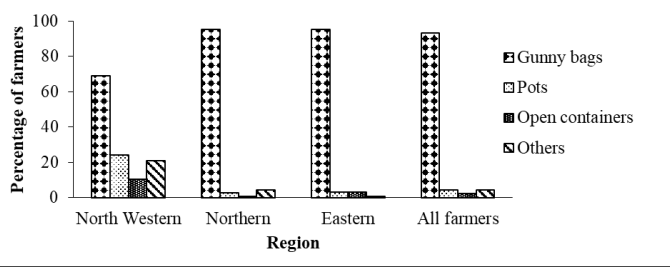

Fig. 6: Bambara groundnut seed Storage methods
Seed processing prior to planting

Farmers used several methods to process seeds before planting, but shelling by hand $(52.0 \%)$ was the dominant method followed by shelling with mortar $(31.2 \%)$. Whereas farmers in Northern (37.3\%) and Eastern (26.4\%) regions used shelling with mortar, none of their counterparts in North

Western region used this method (Figure 7). Farmers also sorted seeds after shelling to remove all undesirable ones.

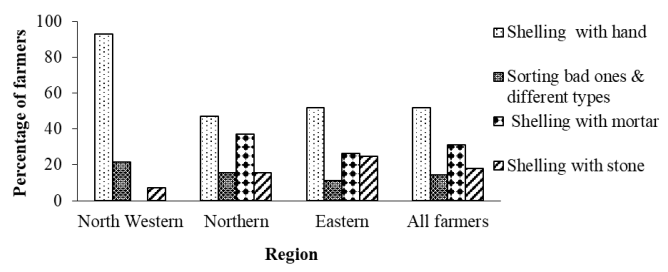

Fig. 7: Bambara groundnut seed processing methods

Seed morphology of collected Bambara groundnut landraces

There was a significant difference among landraces with respect to seed length and width $(p<.001)$. The largest seeds were those of Local Bam $(1.37 \mathrm{~cm}$ and $1.01 \mathrm{~cm}$, length and width respectively) while AbiBam 001 had the smallest seeds $(0.89 \mathrm{~cm}$ and $0.74 \mathrm{~cm})$ (Table 3$)$. Landraces also had varied seed coat colours. Local Bam was brown spotted, TVSU 688 was plain cream, AbiBam 003 was black, AbiBam 001 was cream with black stripes, and TVSU 759 had plain cream, black and brown seeds (Table 4). 
TABLE 3

Comparison of collected Bambara groundnut landraces on the basis of seed size (length and width)

\begin{tabular}{lll}
\hline Landrace & $\begin{array}{l}\text { Seed length } \\
(\mathbf{c m})\end{array}$ & Seed width $(\mathbf{c m})$ \\
\hline AbiBam 001 & $0.89 \mathrm{a}$ & $0.74 \mathrm{a}$ \\
AbiBam 003 & $1.00 \mathrm{bc}$ & $0.84 \mathrm{~b}$ \\
Local Bam & $1.37 \mathrm{~d}$ & $1.01 \mathrm{c}$ \\
TVSU 688 & $1.07 \mathrm{c}$ & $0.83 \mathrm{~b}$ \\
TVSU 759 & $0.94 \mathrm{ab}$ & $0.81 \mathrm{ab}$ \\
\hline CV(\%) & 7.1 & 6.0 \\
LSD & 0.113 & 0.076 \\
F pr. & $<.001$ & $<.001$
\end{tabular}

Means with same letters do not differ significantly ( $p$ $=0.05$ )

TABLE 4

Seed colour description of collected Bambara groundnut landraces

\begin{tabular}{|c|c|c|}
\hline $\begin{array}{l}\text { Lan- } \\
\text { drace }\end{array}$ & $\begin{array}{l}\text { Colour } \\
\text { description }\end{array}$ & Illustration \\
\hline $\begin{array}{l}\text { Local } \\
\text { Bam }\end{array}$ & $\begin{array}{l}\text { Brown } \\
\text { spotted }\end{array}$ & \\
\hline $\begin{array}{l}\text { TVSU } \\
688\end{array}$ & $\begin{array}{l}\text { Plain } \\
\text { cream }\end{array}$ & \\
\hline $\begin{array}{l}\text { AbiBam } \\
003\end{array}$ & Black & \\
\hline $\begin{array}{l}\text { AbiBam } \\
001\end{array}$ & $\begin{array}{l}\text { Cream with } \\
\text { black } \\
\text { stripes }\end{array}$ & \\
\hline $\begin{array}{l}\text { TVSU } \\
759\end{array}$ & $\begin{array}{l}\text { Plain } \\
\text { cream, } \\
\text { black \& } \\
\text { brown }\end{array}$ & \\
\hline
\end{tabular}

Physiological seed quality of collected Bambara groundnut landraces

Landraces showed a significant difference in relation to $\mathrm{EC}(p=0.008)$. Local Bam recorded the highest EC $\left(0.52 \mathrm{MSg}^{-1}\right)$, while TVSU 688 recorded the lowest EC $\left(0.06 \mathrm{MSg}^{-1}\right)$ (Table 5). Landraces also significantly differed in their germination capacity $(p=0.007)$ with TVSU 688 showing the highest germination $(96.0 \%)$ and AbiBam 001 (66.67\%) having the lowest final germination percentage respectively (Table 5). Similarly, significant differences were observed among landraces with respect to Germination Velocity Index $(p=0.040)$, being highest in AbiBam 003 (2.91) and lowest in AbiBam 001 (2.03) (Table 5). There was also a significant difference among landraces with respect to Seedling Vigour Index II ( $p=0.003)$, with local Bam (485.3) and AbiBam 001 (213.3) having the highest and lowest Seedling Vigour Index II respectively (Table 5).

TABLE 5

Final germination percentage (FGP), Germination Velocity Index (GVI), Electrical conductivity (EC) and Seedling Vigour Index II (SVI-II) of collected Bambara groundnut landraces

\begin{tabular}{lllll}
\hline Landrace & $\boldsymbol{F G} \boldsymbol{P}$ & $\boldsymbol{G V I}$ & $\boldsymbol{E C}$ & $\boldsymbol{S V I - I I}$ \\
\hline AbiBam 001 & $66.67 \mathrm{a}$ & $2.03 \mathrm{a}$ & $0.24 \mathrm{ab}$ & $213.3 \mathrm{a}$ \\
AbiBam 003 & $93.33 \mathrm{~b}$ & $2.91 \mathrm{~b}$ & $0.15 \mathrm{ab}$ & $477.3 \mathrm{~b}$ \\
Local Bam & $68.00 \mathrm{a}$ & $2.05 \mathrm{a}$ & $0.52 \mathrm{c}$ & $485.3 \mathrm{~b}$ \\
TVSU 688 & $96.00 \mathrm{~b}$ & $2.70 \mathrm{ab}$ & $0.06 \mathrm{a}$ & $448.5 \mathrm{~b}$ \\
TVSU 759 & $84.00 \mathrm{ab}$ & $2.76 \mathrm{~b}$ & $0.33 \mathrm{bc}$ & $283.6 \mathrm{a}$ \\
\hline LSD & 19.44 & 0.677 & 0.221 & 134.1 \\
F pr. & 0.007 & 0.040 & 0.008 & 0.003 \\
Means with same letters do not differ significantly (p \\
$=0.05)$
\end{tabular}

Relationship between seed size and physiological seed quality

Seed size was negatively correlated with FGP $(r=-0.24$ and -0.19 , seed length and width respectively) and GVI $(\mathrm{r}=-0.36$ and -0.23 , seed length and width respectively) but was positively correlated with SVI-II $(\mathrm{r}=0.71$ and 0.74 , seed length and width respectively) (Table 6). 
TABLE 6

Correlation coefficients of seed size (seed length and width) and physiological seed quality parameters of collected Bambara groundnut landraces

\begin{tabular}{llllll}
\hline & $\begin{array}{l}\text { Seed } \\
\text { length }\end{array}$ & $\begin{array}{l}\text { Seed } \\
\text { width }\end{array}$ & FGP & $\begin{array}{l}\text { SVI- } \\
\text { II }\end{array}$ & GVI \\
\hline Seed length & - & & & & \\
Seed width & 0.97 & - & & & \\
FGP & -0.24 & -0.19 & - & & \\
SVI-II & 0.71 & 0.74 & 0.43 & - & \\
GVI & -0.36 & -0.23 & 0.93 & 0.29 & - \\
\hline
\end{tabular}

\section{Discussion}

\section{Seed sources}

The major seed sources were farmer's own saved seeds and the local market. This is in agreement with Ibrahim et al. (2018) who reported the use of farmer's recycled seed and purchase from local markets as major seed sources for Bambara groundnut in Dosso region of Western Niger. Nevertheless, this study indicated that seed was exchanged among farmers, highlighting a typical characteristic of an informal seed system particularly of a neglected crop like Bambara groundnut. Seed exchange among farmers is attributed to uncertainty about seed savings (Louwaars, 2007). However, seeds obtained from an informal system may have lower quality compared to those from the formal system, possibly due to the quality control in the formal system (Biemond, 2013).

\section{Seed composition}

Farmers' seed composition was mostly single and mixed landraces although some reported having "more than one but not mixed" landraces. A similar seed composition among Bambara groundnut farmers in North Eastern Nigeria was reported by Aviara et al. (2013). Furthermore, heterogenous mixtures of Bambara groundnut seed has been shown to be common among farmers in Sub-Saharan Africa
(Mohammed et al., 2016). Non-improved crops such as Bambara groundnut tend to be mixed yet farmers are not very keen to sort them according to different categories. This implies that even the category "more than one but not mixed" landraces can be a mixed type upon threshing and observing the seeds. A mixed landrace may not entirely entail poor seed quality but performance-wise, different landraces in the mixture may have different maturity periods, yields and responses to environmental factors. A case in point is Bambara groundnut landraces varied reaction to Fusarium wilt infection (Wakhungu, 2016) and water stress (Chibarabada, 2014). Such diversity could have implication on subsequent yield and seed quality. In addition, sowing of mixed seeds of a crop species results in nonuniform field stand establishment, causing heterogeneity in the vigour of plants (Mishra et al., 2010).

\section{Period of seed recycling}

Farmers frequently recycled seed for more than four years (four times). This corroborates with Aviara et al. (2013) who reported that local communities in North Eastern Nigeria selected and maintained Bambara groundnut landraces for long periods. Increased periods of seed recycling leads to poor seed quality and low yields particularly in hybrids, with minimal effects on open-pollinated varieties (Amaza et al., 2010; Warburton et al., 2010; Clayton et al., 2009). However, seed recycling is likely to have a minimal effect on the seed quality of Bambara groundnut which is autogamous (Gonné et al., 2013). It is therefore likely that farmers' seed handling practices during recycling periods are a major determinant of seed quality (Gebeyehu et al., 2019). 


\section{Seed selection}

Seed was largely selected at drying and planting. Farmers who select seeds at planting run the risk of losing seed as it may be sold or consumed in the household, but they ensure that they plant good quality seeds. On the other hand, seed selection at drying ensures that seeds are stored separately and, in most cases, handled differently from the grains, for example, re-drying to prevent mould growth. Interestingly, however, most of the farmers did not use any criterion to select seeds, although big-sized pods, high-yielding plants and healthy-looking plants and pods were used by a few farmers. Supply of seeds for crops such as Bambara groundnut are entirely informal, hence seed selection is done either from farmer's production or other sources (Louwaars, 2007).

\section{Seed drying}

Bambara groundnut seeds were typically sundried on the ground. This was the common practice probably because it is a cheap and convenient method. Farmers normally harvest Bambara groundnut when the pods are already detached from the plant, hence alternative drying methods such as hanging or bunching as with groundnuts are not possible. In addition, access to tarpaulins or construction of a raised drying platform is usually a challenge for most farmers. Sun-drying of Bambara groundnut is commonly done by farmers in Dosso region of Western Niger (Ibrahim et al., 2018). Sundrying of seeds directly on the ground for both grain legumes and cereals is practiced by most farmers in Eastern Kenya (Njoroge et al., 2019). This practice is likely to cause infestation by aflatoxin causing fungi Aspergillus flavus which would have a negative health impact if seeds are consumed as food (Adithya et al., 2016). However, farmers in our study reported drying Bambara groundnut seeds when in pods, thus it would also be necessary to establish the level of fungal infestation on both the seeds and pods under different drying methods.

\section{Seed storage}

Seed was mostly stored in gunny bags and placed on raised platforms (on stone, top of other produce or timber). The non-hermetic bags are the most common storage materials used by farmers because they are readily available, affordable and adequately aerated, providing short to medium term storage (Sultana et al., 2016; Jebuni, 2014). Placing the bags on raised platforms keeps seeds free from dampness that could cause mould growth and seed deterioration. Storage of Bambara groundnut in pots and local granaries made of grass materials by farmers in North Eastern Nigeria has been reported (Aviara et al., 2013). However, the use of such structures resulted in high insect pest infestation for seeds in shelled conditions (Aviara et al., 2013). Farmers in our study reported storage of Bambara groundnut in pods (unshelled condition). Bambara groundnut pods are very hard when dry and insect infestation and damage on seeds stored in pods is likely to be minimal.

\section{Seed processing prior to planting}

Threshing of pods to obtain seeds prior to planting was mostly done using the hands, pounded in a mortar with a pestle, or cracked with a stone. Information on seed processing indicates that seed shelling by mortar and pestle, stones and treading with feet is commonly practiced among Bambara groundnut farmers in Dosso region of Western Niger and North Eastern Nigeria (Ibrahim et al., 2018; Aviara et al., 2013). Other methods include pouring pods into jute or hessian bags and beating with sticks on flat surfaces, and beating jute or hessian 
bag containing the pods against the wall of a building (Aviara et al., 2013). However, these methods involve the application of force to the seeds, which is likely to cause more mechanical damage to the seeds as compared to shelling with hand, although some care is taken when exercising these methods. Mechanical damage on the seed tissues has implication on seed quality. Comparison of manual and mechanical threshing of maize at $12 \%$ moisture content revealed that mechanical damage on the seeds was higher for mechanical threshing, resulting in lower germination capacity and seed vigour as compared with manual threshing (Riliang et al., 2019). Determining the extent of mechanical damage of different seed threshing methods on the seeds and correlating with physiological seed quality would help in advising Bambara groundnut farmers on appropriate seed threshing methods.

\section{Seed morphology}

Landraces showed variability not only in their seed coat colours but also in their sizes, with Local Bam and AbiBam 001 having the largest and smallest seeds respectively. This variability could be explained by the production of heterogenous seeds by plants for their survival (Imbert, 2002). Heterogeneity in seeds usually happens due to physiological, environmental and genetic factors (Bhatt et al., 2016) and is exhibited by features such as colour, size and shape (Matilla et al., 2005). Seed heterogeneity is also known to affect seed germination (Smith et al., 2004; Bhatt et al., 2016). Bambara groundnut landraces differing in their seed coat colours have been reported to have varying seed coat thickness, water imbibition and germination capacity (Mandizvo \& Odindo, 2019; Chibarabada et al., 2014). Seed colour also affects the light and temperature requirement of seeds during germination (Bhatt et al., 2016). On the other hand, seed size is an important indicator of physiological seed quality as it affects seed germination and seedling growth particularly under stress conditions (Steiner et al., 2019). Seed size is also known to affect field emergence, plant growth and performance in the field (Adebisi et al., 2013). Generally, large seeds have higher vigour than small seeds due to more accumulated reserves (Ambika et al., 2014). The first germination count test of small peanut seeds was higher than that of large seeds of the same crop in both non-stressful and water-stressful conditions, indicating a delay in the germination process of large seeds (Steiner et al., 2019). Similarly, the germination speed index of large-sized wheat seeds was reportedly lower than that of medium and small-sized seeds (Shahi et al., 2015). The high germination rate in small-sized seeds is attributed to their less need for water absorption hence imbibing water faster than large-sized seeds (Steiner et al., 2019; Sadeghi et al., 2011). However, the effect of seed size on seed germination and crop establishment varies between crop species and growth environments (Shahi et al., 2015; Rastegar \& Kandi, 2011; Gholami et al., 2009).

\section{Physiological seed quality \\ Germination capacity}

Germination capacity varied among landraces with the highest percentage in TVSU 688 (96.0\%) and the lowest in AbiBam 001 $(66.67 \%)$. Seed harvesting stage is known to affect the germination capacity of seeds as the stage at which the crops are harvested directly relates to the physiological state (development and maturation) of seeds. Evaluation of three soybean varieties revealed that germination capacity of $85.25 \%, 77.25 \%$ and $67.33 \%$ in Nangbaar, $85.25 \%, 68.0 \%$ and $60.92 \%$ in Anidaso, $66.75 \%, 64.67 \%$ and $58.83 \%$ in Jeguma varieties were attained when seeds were harvested at physiological maturity, one 
week after physiological maturity and two weeks after physiological maturity respectively (Isaac et al., 2016). It is therefore likely that seeds harvested at different times will have different germination capacities, as exhibited in this study. However, it was not possible to pinpoint the exact maturity stages of seeds used in this study since the seed samples were collected from different farmers. Seed handling practices such as drying (how long and to what moisture content) and storage (storage materials, duration and storage conditions) could also account for such differences observed in FGP of landraces. The germination pattern observed in this study could also be explained by the seed coat colours of landraces. This study revealed that the light coloured (plain cream) landrace (TVSU 688) had the highest germination percentage, which is in agreement with Mandizvo and Odindo (2019) who reported higher germination percentages in light coloured Bambara groundnut landraces at the University of KwaZulu-Natal, South Africa.

\section{Seed vigour}

Local Bam recorded the highest EC (0.52 $\mathrm{MSg}^{-}$

$\left.{ }^{1}\right)$ while TVSU 688 recorded the lowest (0.06 $\mathrm{MS} \mathrm{g}^{-1}$ ) among the landraces. Electrical conductivity test measures the concentration of leachates discharged into the solution, which is linked to the integrity of seed coat membrane (Binotti et al., 2008). Differences in EC observed in landraces could be due to differences in their seed coat structure particularly number and size of pores which are likely to influence electrolyte leakage from imbibed seeds. In addition, seed handling practices such as storage (storage period and conditions which influence seed ageing) and seed threshing methods (which may cause mechanical damage in seed coat) influence electrolyte leakage from the seeds (Vishwanath et al., 2019). Mechanical damage on the seed tissues has been reported to be positively correlated with EC of seeds (Ri-liang et al., 2019). Electrical conductivity of a seed lot has been further demonstrated to be influenced by seed age and initial seed moisture content (Ferreira et al., 2017; Vieira, 1994). Still another study suggested that seed coat thickness determines leakages of electrolytes from the seed (Sinefu, 2011), though this was disputed by Chibarabada et al. (2014) who found no relationship between electrical conductivity and seed coat thickness. The same study by Chibarabada et al. (2014) reported that Bambara groundnut landrace with highest calcium content had lowest electrical conductivity and they attributed it to greater cell wall integrity due to high calcium content. However, the underlying seed coat structure (seed coat thickness, number and size of pores on the seed coat), seed mineralogy and the extent of mechanical damage on the seeds were not determined for the landraces in our study. Besides, it was not possible to trace a specific landrace and pinpoint its exact seed age (duration of storage) and storage conditions (relative humidity and temperature) by the time of this analysis. Therefore, a more detailed study on seed coat structure, seed mineralogy and age of these landraces would give more light on the electrical conductivity exhibited.

AbiBam 003 a dark-coloured (plain black) landrace had the highest germination velocity index among the landraces. This corroborates with Chibarabada et al. (2014) who reported the highest germination velocity index in black speckled Bambara groundnut seeds. This is related to the rapid water imbibition in dark coloured seeds which is likely to cause faster initiation of the germination process (Mandizvo \& Odindo, 2019). From EC, GVI and FGP, Local Bam had less vigour and low germination capacity. Interestingly, however, the same landrace 
had the highest seedling vigour index II. This suggests that Local Bam seed lot could be less vigorous but the individual seeds that germinated had high vigour, which was demonstrated by seedling growth. Local Bam had the largest seeds, which is an indication of large food reserves that cause rapid seedling growth upon hydrolysis and translocation to the growing regions. This study also revealed that seed size was positively correlated with seedling vigour index II, indicating a higher vigour for those seedlings arising from large seeds. Seeds of different sizes have different levels of food reserves hence determining the initial growth of seedlings (Shahi et al., 2015). Large seeds of peanut produce seedlings with higher dry weight and seedling weight vigour (seedling vigour index II) than small seeds in both stress and non-stressed conditions (Steiner et al., 2019). Similarly, large-sized seeds of soybean were reported to produce plants with the highest shoot dry matter (Limede et al., 2018).

\section{Conclusion and Recommendations}

Bambara groundnut landraces obtained from farmers were evaluated to establish their seed quality in relation to farmers' practices. The landraces TVSU 688, TVSU 759 and AbiBam 003 showed relatively good seed quality in terms of germination capacity and electrical conductivity except, TVSU 759 whose EC did not seem to correspond to the good germination. Despite Local Bam having a relatively low germination capacity and high electrical conductivity that would suggest low quality, it recorded the highest seedling vigour index apparently because of its relatively large seed size. The relatively good seed quality exhibited suggests that seed management practices commonly adhered to by farmers such as proper drying and unshelled storage in gunny bags placed on raised platforms that minimizes seed deterioration from dampening and pest infestation are important in seed quality maintenance in farmer saved seeds. Farmers should therefore be trained on good seed handling techniques so as to improve on the quality of their farm saved seeds.

A similar study targeting Bambara groundnut farmers from other parts of Uganda should also be done to find out their practices, landrace types and the seed quality of those landraces they are growing. Determining the level of mechanical damage imposed on the seed by different seed threshing methods and correlating with physiological seed quality would help in advising farmers on appropriate seed threshing methods. Studies on seed coat structure and mineralogy of landraces used in this study would also help in explaining the observed seed quality.

\section{Acknowledgement}

This study was funded by the Intra-Africa Academic Mobility Scheme of the European Union through SCIFSA project.

\section{REFERENCES}

Abdul-Baki, A. A. \& Anderson, J. D. (1973) Vigor Determination in Soybean Seed by Multiple Criteria. Crop Science 13 (6), 630 - 633.

Adebisi, M. A., Kehinde, T.O., Salau, A.W., Okesola, L.A., Porbeni, J.B.O., Esuruoso, A.O. \& Oyekale, K.O. (2013) Influence of Different Seed Size Fractions on Seed Germination, Seedling Emergence and Seed Yield Characters in Tropical Soybean (Glycine max L. Merrill). International Journal of Agricultural Research 8 (1), 26 - 33.

Adebowale, K.O. \& Lawal, O.S. (2002) Effect of Annealing and Heat Moisture Conditioning on the Physicochemical Characteristics of Bambara groundnut (Voandzeia subterranean) Starch and Flour. Food Chemistry 78, $305-311$. 
Adithya, G., Rajeshwari, B., Keshavulu, K. \& Sudini, H. (2016) Effect of Aspergillus flavus on Ground Nut Seed Quality Under Different Periods of Incubation in Cultivar J11 and JL 24. Progressive Research 11, 2194 - 2197.

Amaza, P., Udoh, E., Abdoulaye, T. \& Kamara, A. (2010) Analysis of Technical Efficiency among Community-based Seed Producers in The Savannas of Borno State, Nigeria. Journal of Food, Agriculture and Environment 8, $1073-1079$.

Ambika, S., Manonmani, V. \& Somasundaram, G. (2014) Review on Effect of Seed Size on Seedling Vigour and Seed Yield. Research Journal of Seed Science 7 (2), 31 - 38.

Anchirinah, V.M., Yiridoe, E.K. \& Benneh-Lartey, S.O. (2001) Enhancing Sustainable Production and Genetic Resources Conservation of Bambara groundnut: A Survey of Indigenous Agricultural Knowledge System. Outlook on Agriculture 30 (4), 281 - 288.

APG IV. (2016) Angiosperm Phylogeny Group. "An Update of the Angiosperm Phylogeny Group Classification for the Orders and Families of Flowering Plants: APG IV" (PDF). Botanical Journal of the Linnean Society 181,1 - 20.

Aviara, N.A., Lawal, A.A., Atiku, A.A. \& Haque, M.A. (2013) Bambara groundnut Processing, Storage and Utilization in North Eastern Nigeria. Continental Journal of Engineering Sciences 8 (1), 28 - 36.

Bamishaiye, O.M., Adegbola, J.A. \& Bamishaiye, E.I. (2011) Bambara groundnut: An Under-utilized nut in Africa. Advances in Agricultural Biotechnology 1, 60 - 72 .

Basra, A.S. (1995) Seed Quality: Basic Mechanisms and its Implications in Agriculture. New York: Harworth Press.

Bhatt, A., Gairola, S. \& El-Keblawy, A.A. (2016) Seed Colour Affects Light and Temperature Requirements during Germination in two Lotus Species (Fabaceae) of the Arabian Subtrop- ical Deserts. Internationl Journal of Troipical Biology 64 (2), 483 - 492.

Biemond, P.C. (2013) Seed Quality in Informal Seed Systems. PhD Thesis, Wageningen University, The Netherlands.

Binotti, F.F.S., Haga, K.I., Cardoso, E.D., Alves, C.Z., Sá, M.E. \& Arf, O. (2008) Effect of the Accelerated Aging Period in the Electrical Conductivity Test and in the Physiological Quality of Bean Seeds. Acta Scientiarum Agronomy 30 (2), 247 - 254.

Chibarabada, T.P. (2014) Seed Quality and Water Use Characteristics of a Bambara groundnut (Vigna subterranea L.) Landrace Differing in Seed Coat Colour. MSc. Thesis, University of KwaZulu-Natal, Pietermaritzburg, South Africa.

Chibarabada, T.P., Modi, A.T. \& Mabhaudhi, T. (2014) Seed Quality Characteristics of a Bambara groundnut (Vigna subterranea L.) Landrace Differing in Seed Coat Colour. South African Journal of Plant and Soil 31 (4), 219 -226 .

Clayton, G.W., Brandt, S., Johnson, E.N., O'Donovan, J.T., Harker, K.N., Blackshaw, R.E., Smith, E.G., Kutcher, H.R., Vera, C. \& Harman, M. (2009) Comparison of Certified and Farm Saved Seed on Yield and Quality Characteristics of Canola. Agronomy Journal 101, $1581-1588$.

Effa, E.B. \& Uko, A.E. (2017) Food Security Potentials of Bambara groundnut (Vigna subterranea (L.) Verdc.). International Journal of Development and Sustainability 6 (12), 1919 - 1930.

FAO. (2019) FAOSTAT. Production/Yield quantities of Bambara Beans in Africa 1994 -2017 http:// www.fao.org/faostat/en/\#data/QC/visualize

Ferreira, L.B.S., Fernandes, N.A., Aquino, L.C., Rodrigo, A.S., Nascimento, W.M. \& Leão-Araújo, E.F. (2017) Temperature and seed moisture content affect electrical conductivity test in pea seeds. Journal of Seed Science 39 (4), $410-416$. 
Gebeyehu, S., Kangile, J. \& Mwakatobe, E. (2019) Assessment of Seed Quality along The Rice Seed Value Chain in Tanzania. Development in Practice 29 (7), 854 - 866.

Gholami, A., Sharafi, S., Sharafi, A. \& Ghasemi, S. (2009) Germination of Different Seed Size of Pinto Bean Cultivars as Affected by Salinity and Drought Stress. Journal of Food, Agriculture and Environment 7 (2), 555 - 558.

Gonné, S., Félix-Alain, W. \& Benoît, K.B. (2013) Assessment of Twenty Bambara groundnut (Vigna subterranea (L.) Verdcourt) Landraces using Quantitative Morphological Traits. International Journal of Plant Research 3 (3), $39-45$.

Halimi, A.R., Mayes, S., Barkla, B. \& King, G. (2019) The Potential of the Underutilized Pulse Bambara groundnut (Vigna subterranea (L.) Verdc.) for Nutritional Food Security. Journal of Food Composition and Analysis 77, $47-59$.

Harouna, D.V., Kawe, P.C. \& Mohammed, E.M.I. (2018) Under-Utilized Legumes as Potential Poultry Feed Ingredients: A Mini- Review. Archives of Animal and Poultry Sciences 1 (1), $001-003$.

IBM Corporation. (2011) IBM SPSS Statistics for Windows, Version 20.0. Armonk, New York, USA

Ibrahim, A.R., Dansi, A., Salifou, M., Ousmane, A., Alzouma, A. \& Alou, W. (2018) Farmers' Practices, Utilization, Conservation and Marketing of Bambara groundnut (Vignasubterranea (L.) Verdc.) in Dosso Region, Western Niger. Genetic Resources and Crop Evolution 65 (7), 1907 - 1914.

Imbert, E. (2002) Ecological Consequences and Ontogeny of Seed Heteromorphism Perspect. Plant Ecology, Evolution and Systematics 5, $13-36$.

Isaac, O.T., Banful, B.K., Amoah, S., Apuri, S. \& Seweh, E.A. (2016) Effect of Harvesting
Stages on Seed Quality Characteristics of Three Soybean (Glycine max (L) Merrill) Varieties. Journal of Scientific and Engineering Research 3 (4), 326 - 333.

Jebuni, S.N. (2014) Evaluation of Farmers Storage Structures and Their Effects on The Quality of Sorghum Grain in Wa West District in the Upper West Region of Ghana. MSc. Thesis. Kwame Nkrumah University of Science and Technology, Kumasi, Ghana.

Jonah, P. M., Adeniji, O. T. \& Wammand, D. T. (2010) Variability and Genetic Correlations for Yield and Yield Characters in some Bambara groundnut (Vigna subterranea) Cultivars. International Journal of Agriculture and Biology 12 (2), $303-307$.

Limede, A.C., Oliveira, C.E.S., Zoz, A., Zuffo, A.M., Steiner, F. \& Zoz, T. (2018) Effects of Seed Size and Sowing Depth in the Emergence and Morphophysiological Development of Soybean Cultivated in Sandy Texture Soil. Australian Journal of Crop Science 12 (1), 93 98.

Louwaars, N. (2007) Seeds of Confusion; The Impact of Policies on Seed Systems. PhD Dissertation, Wageningen, The Netherlands.

Maguire, J.D. (1962) Speed of Germination-aid in Selection and Evaluation for Seedling Emergence and Vigor. Crop Science 2, 176 - 177.

Mandizvo, T. \& Odindo, A.O. (2019) Seed Coat Structural and Imbibitional Characteristics of Dark and Light-Coloured Bambara groundnut (Vigna subterranea L.) landraces. Heliyon 5e01249: $1-21$.

Matilla, A., Gallardo, M. \& Puga-Hermida, M.I. (2005) Structural, Physiological and Molecular Aspects of Heterogeneity in Seeds: A Review. Seed Science Research 15, 63 - 76.

Mayes, S., Basu, S., Murchie, E., Roberts, J., AzamAli, S.N., Stadler, F., Mohler, V., Wenzel, G., Massawe, F. \& Kilian, A. (2008) BAMLINK-A Cross Disciplinary Programme to En- 
hance the Role of Bambara Groundnut (Vigna subterranea [L.] Verdc.) for Food Security in Africa and India. International Symposium on Underutilized Plants for Food Security, Nutrition, Income and Sustainable Development, Acta Horticulturae806 International Society for Horticultural Science, 2009, 137 - 150.

Mishra, A., Swamy, S.L., Bargali, S.S. \& Singh, A.K. (2010) Tree Growth, Biomass and Productivity of Wheat Under Five Promising Clones of Populus deltoides in Agrisilviculture System. International Journal of Ecology and Environmental Sciences 36, $167-174$.

Miya, S.P. \& Modi, A.T. (2017) Overcoming the Physical Seed Dormancy in Bambara Groundnut (Vigna subterranea L.) by Scarification: A Seed Quality Study. Journal of Agricultural Science and Technology B 7, 13 - 24.

Mohammed, M. S., Shimelis, H. A. \& Laing, M. D. (2016) Preliminary Investigation on Some Agronomic and Morphological Variations of Within and Between Bambara groundnut Landraces. Journal of Agricultural Science and Technology 18, 1909 - 1920.

Nichols, M. A. \& Heydecker, W. (1968) Two Approaches to The Study of Germination Data. Proceedings of the International Seed Testing Association 33, 531 - 540.

Njoroge, A.W., Baoua, I. \& Baributsa, D. (2019) Postharvest Management Practices of Grains in the Eastern Region of Kenya. Journal of $\mathrm{Ag}$ ricultural Science 11 (3), 33 - 42.

Patel, J.V., Antala, D.K. \& Dalsaniya, A. N. (2018) Influence of Different Packaging Materials on the Seed Quality Parameters of Chickpea. International Journal of Current Microbiology and Applied Sciences 7 (12), 2458 - 2467

Rastegar, Z. \& Kandi, M.A.S. (2011) The effect of Salinity and Seed Size on Reserve Utilization and Seedling growth of Soybean (Glycine max). International Journal of Agronomy and Plant production 2, 1 - 4 .
Ri-liang, G., Ran, H., Guang-yao, J., Zhi-peng, Y., Li-sha, R., Li, L. \& Jian-hua, W. (2019) Effect of Mechanical Threshing on Damage and Vigor of Maize Seed Threshed at Different Moisture Contents. Journal of Integrative Agriculture 18 (7), 1571 - 1578.

Sadeghi, H., Khazaei, F., Sheidaei, S. \& Yari, L. (2011) Effect of Seed Size on Seed Germination Behavior of Safflower (Carthamus tinctorius L.). ARPN Journal of Agricultural and Biological Sciences 6, 5-8.

Shahi, C., Vibhuti., Bargali, K., \& Bargali., S. S. (2015) How Seed Size and Water Stress Effect the Seed Germination and Seedling Growth in Wheat Varieties? Current Agriculture Research Journal 3 (1), $60-68$.

Sinefu, F. (2011) Bambara groundnut Response to Controlled Environment and Planting Date Associated Water Stress. MSc Thesis, University of KwaZulu-Natal, Pietermaritzburg, South Africa.

Smith, S.M., Jenkinson, M., Woolrich, M.W., Beckmann, C.F., Behrens, T.E., Johansen-Berg, H., Bannister, P.R., De Luca, M., Drobnjak, I., Flitney, D.E., Niazy, R.K., Saunders, J., Vickers, J., Zhang, Y., De Stefano, N., Brady, J.M. \& Matthews, P.M. (2004) Advances in Functional and Structural MR Image Analysis and Implementation as FSL. Neuroimage 23 (Suppl 1), S208 - S219.

Sprent, J.I, Odee, D.W. \& Dakora, F.D. (2010) African Legumes: A Vital but Under-utilized Resource. Journal of Experimental Botany $\mathbf{6 1}$ (5), $1257-1265$.

Steiner, F., Zuffo, A.M., Busch, A., Sousa, T.O. \& Zoz, T. (2019) Does Seed Size Affect the Germination Rate and Seedling Growth of Peanut under Salinity and Water Stress? Pesquisa Agropecuaria Tropical 49, 1 - 9.

Sultana, N., Ali, Y., Jahan, S. \& Yasmin, S. (2016) Effect of Storage Duration and Storage Devices on Seed Quality of Boro Rice Variety BRRI 
dhan47. Journal of Plant Pathology and Microbiology 8 (1), $1-6$.

Tsoata, E., Temegne, N. C. \& Youmbi, E. (2016) Analysis of Early Physiological Criteria to Screen four Fabaceae Plants for their Tolerance to Water Stress. International Journal of Recent Scientific Research 7 (11), 14334 14338.

Vieira, R.D. (1994) Electrical Conductivity Test. In: Vieira, R.D., \& Carvalho, N.M. (Eds.). Seed Vigour Tests. Jaboticabal: FUNEP,103 - 132.

Vishwanath, R.H., Gurumurthy, R. \& Manjunatha, M.V. (2019) Influence of Seed Processing and Storage on Seed Quality of Soybean Var. DSb21. International Journal of Current Microbiology and Applied Sciences 8 (1), 1684 - 1694.
VSN International. (2011) GenStat for Windows $14^{\text {th }}$ Edition. VSN International Ltd, Hemel Hempstead, UK.

Wakhungu, C.N. (2016) Screening of Selected Bambara Nut (Vigna subterranea (L.) Verdc) Landraces for Tolerance to Fusarium Wilt and its Management Using Farmyard Manure in Busia County, Western Kenya. MSc. Thesis, Egerton University, Kenya.

Warburton, M.L., Setimela, P., Franco, J., Cordova, H., Pixley, K., Bänziger, M., Dreisigacker, S., Bedoya, C. \& MacRobert, J. (2010) Toward A Cost-effective Fingerprinting Methodology to Distinguish Maize Open-pollinated Varieties. Crop Science 50, 467 - 477. 